\title{
Importance of Medico Legal Expert at Scene of Crime Related to Death
}

\author{
Vinod Dhingra*1 and Sarthak Juglan² \\ ${ }^{1}$ Senior Scientific Officer, India \\ ${ }^{2}$ HOD Forensic Medicine, India
}

Submission: November 02, 2017; Published: November 13, 2017

*Corresponding author: Dr Vinod Dhingra, Senior Scientific Officer, In charge officer Scene of crime mobile unit S P office Gwalior, MP, India, Email: vdhingraso@hotmail.com

Abstract

Medical expertise is crucial in death investigations. It begins with body examination and evidence collection at the scene and proceeds through history, physical examination, laboratory tests, and diagnosis-in short, the broad ingredients of a doctor's treatment of a living patient. The key goal is to provide objective evidence of cause, timing, and manner of death for adjudication by the criminal justice system. In homicide, suspected homicide, and other suspicious or obscure cases, the medico legal expert should visit the scene of the death before the body is removed. Local practice varies but any doctor claiming to be a forensic medicine expert should always make him available to accompany the police to the locus of the death. In many cases, the scene investigation is more important than the autopsy. A thorough and complete investigation commonly leads to the proper diagnosis of the cause and manner of death prior to an autopsy.

The present article highlights the importance of medico legal experts at death scene for effective crime scene forensic investigation at the incident place, where they can suggest the actual facts for criminal justice system some of these facts may disappear when body moved for post mortem examination and directive tips for effective crime scene investigation applying their expertise.

Keywords: Forensic examination; Medico legal experts; Crime scene investigation

\section{Introduction}

Medical expertise is crucial in death investigation [1-4]. It begins with body examination and evidence collection at the scene and proceeds through history, physical examination, laboratory tests, and diagnosis in short, the broad ingredients of a doctor's treatment of a living patient [5-7]. The key goal is to provide objective evidence of cause, timing, and manner of death for adjudication by the criminal justice system. Death investigation has been performed for centuries in all societies, although the primary goal of a death investigation is to establish the cause and manner of death, in death investigation is to benefit the living and future generations [8].

In homicide, suspected homicide, and other suspicious or obscure cases, the medico legal expert should visit the scene of the death before the body is removed. Local practice varies but any doctor claiming to be a forensic medicine expert should always make him available to accompany the police to the locus of the death. In many cases, the scene investigation is more important than the autopsy. A thorough and complete investigation commonly leads to the proper diagnosis of the cause and manner of death prior to an autopsy $[9,10]$.
The purpose of having the medico legal expert attend the death scene is several folds. By viewing the body in the context of its surroundings, the forensic medicine expert is better able to interpret certain findings at the autopsy such as a patterned imprint across the neck from collapsing onto an open vegetable drawer in a refrigerator. The forensic medicine expert is also able to advise the investigative agency about the nature of the death, whether to confirm a homicide by a specific means, evaluate the circumstances to be consistent with an apparent natural death, or interpret the blood loss from a deceased person as being more likely due to natural disease than to injury. The thorough examination of a death scene requires a disciplined and systematic approach to recording the various observations made and collection of potential evidential material. This must if resources are sufficient and the circumstances of death so dictate, it is ideal for a forensic medicine expert to perform a scene investigation. Every death scene is a potential crime scene. It is important to carefully examine the scene for evidence or unusual circumstances that may indicate the death of the person is other than by natural causes. 


\section{Various Actions Taken at Crime Scene}

Death scene investigation may include a combination of the following types of incidents and examinations:

a) Accidental deaths, which include a multitude of circumstances, including misadventure.

b) Suicidal deaths, which include a multitude of circumstances.

c) Homicidal deaths, which include a multitude of circumstances.

d) Sudden deaths, with or without suspicious circumstances.

e) Difficult victim identification, which includes mummification and putrefaction.

f) Disaster victim identification dealing with multiple casualties.

\section{Investigative Tools and Equipment Required at Crime Scene}

The forensic medicine expert should always have appropriate equipment ready to take to a scene investigation at a short notice. They are

a) Water proof apron and rubber gloves.

b) Writing implements (pens, pencils, markers).

c) Disposable (paper) jumpsuits, hair covers, face shield, etc.

d) Thermometer, syringes and needles, sterile swabs.

e) Autopsy dissection set, including hand-saw.

f) Cutting needles and twine for body closure.

g) Swabs and containers for blood and body fluids.

h) Formalin jars for histological samples.

i) Plastic bags, envelopes, paper, spare pen and pencil.

j) Printed body charts for recording external injuries.

k) Hand lens, electric torch, mini-tape recorder.

l) Foul-weather gear (raincoat, umbrella, etc.).

m) Personal comfort supplies (insect spray, sun screen, hat, etc.).

n) Camera, usually $35 \mathrm{~mm}$ single-lens reflex with electronic flash (with extra battery).

o) Clothing such as rubber boots and rain or snow-wear.

\section{Steps of Death Scene Investigation}

The deceased is the most valuable piece of potential evidence at any death scene. Blood spillage or spatter should be noted and will remain after the removal of the body. The forensic medicine expert should focus on the physical condition of a body at a scene. Without a scene investigation, much initial, valuable body information can be lost. The following points will serve as a guide.

a) Planning of the death scene investigation

b) Cooperation among investigators

c) Documentation of the scene

d) Taking notes at the death scene

e) Videotaping, photographing and sketching at the death scene

f) Identification of the deceased and examination of the body

g) Scene information collection

h) Collecting evidences which may be found at the death scene

i) Interviewing persons regarding the death

j) Estimating the post-mortem interval at the scene

k) Ending the death scene investigation

\section{Various Crime Scene Incidents}

a) Homicide

b) Homicide by poisoning

c) Suicide

d) Accident

e) Natural deaths

f) Sudden and unexplained infant death.

\section{Conclusion}

The medico legal expert should visit the death scene before the autopsy if it is possible. Although, death investigation differs in different countries, there is always a crime scene investigation team. If the medico legal expert does not have the opportunity to visit the death scene himself, he would check the documents (notes, sketches, photographs, etc) which crime scene investigation team prepared. Many medico legal deaths may be resolved by death scene investigation. A medico legal expert should never forget: If the death scene investigation is not performed before the autopsy, that autopsy will be an imperfect autopsy.

The forensic medicine expert should visit the death scene before the autopsy if it is possible. In some cases, it is important to distinguish accidental manner from suicidal or homicidal ones. For example, if a ligature mark is present on the neck, this is usually suicide or homicide. Children have an increased 
risk for injury or death from accidents for a variety of reasons compared to adults. Accidental asphyxia can occur in childhood as a result of variety situations.

\section{References}

1. Clark SC (1999) Death Investigation: A Guide for the Scene Investigator National Institute of Justice, Washington, USA.

2. Corey TS, Hanzlick R, Howard J, Nelson C, Krous H (2007) A functional approach to sudden unexplained infant deaths. Am J Forensic Med Pathol 28(3): 271-277.

3. DiMaio VJ, DiMaio D (2001) Forensic Pathology ( $2^{\text {nd }}$ edn.), Florida, USA. In Dix J, Calaluce R, Ernst MF (Eds.), Guide to Forensic Pathology, Florida, USA.

4. Horswell J (2005a) Major incident scene management In: Encyclopedia of Forensic and Legal Medicine. In Payne James J, Byard R, Corey T, Henderson C (Eds.), Academic Press, London, UK, pp.12-20.
5. Horswell J (2005b) Suspicious deaths In: Encyclopedia of Forensic and Legal Medicine. In Payne James J, Byard R, Corey T, Henderson C (Eds,). Academic Press, London, pp. 32-36.

6. Lee HC, Palmback T, Miller MT (2000) Henry Lee's Crime Scene Handbook. Academic Press, California, USA.

7. Miller MT (2003) Crime scene investigation In: Forensic Science: An Introduction to Scientific and Investigative Techniques. In James $\mathrm{SH}$, Nordby JJ, Florida (Eds.), USA, pp. 115-135.

8. Prahlow J (2010) Forensic Pathology for Police Death Investigators, Attorneys and Forensic Scientists. New Jersey, USA.

9. Saukko P, Knight B (2004) Knight's Forensic Pathology ( $3^{\text {rd }}$ edn), London.

10. Wagner SA (2009) Death Scene Investigation - A Field Guide. Florida USA.
This work is licensed under Creative

Commons Attribution 4.0 License

DOI: 10.19080/JFSCI.2017.05.555682
Your next submission with Juniper Publishers will reach you the below assets

- Quality Editorial service

- Swift Peer Review

- Reprints availability

- E-prints Service

- Manuscript Podcast for convenient understanding

- Global attainment for your research

- Manuscript accessibility in different formats ( Pdf, E-pub, Full Text, Audio)

- Unceasing customer service

Track the below URL for one-step submission https://juniperpublishers.com/online-submission. 